\title{
ELECTROFLOCCULATION APPLIED TO THE TREATMENT OF OIL
} PRODUCTION WASTEWATER

\section{APLICAÇÃO DA ELETROFLOCULAÇÃO NO TRATAMENTO DE EFLUENTES GERADOS NA PRODUÇÃO DE ÓLEO}

\author{
RODRIGUES, Bárbara Martins"; CERQUEIRA, Alexandre Andrade²; RUSSO, Carlos¹; MARQUES, \\ Monica Regina da Costa ${ }^{2}$
}

\author{
${ }^{1}$ Universidade do Estado do Rio de Janeiro, Pavilhão Haroldo Lisboa da Cunha, Instituto de Química, \\ Laboratório de Tecnologia Ambiental, Rua São Francisco Xavier, 524, 20550-013. Rio de Janeiro - RJ, Brasil \\ ${ }^{2}$ Programa de Pós-Graduação em Meio Ambiente (PPG-MA) Doutorado Multidisciplinar \\ *e-mail: alexandrecerq@ig.com.br
}

Received 16 May 2010; received in revised form 7 July 2010; accepted 10 July 2010

\section{RESUMO}

A demanda para tratamento de efluentes industriais tem sido maior a cada dia e a indústria tem buscado melhoria constante nos processos para tratamento, tendo como referência a resolução CONAMA 357/2005. Nesse contexto, a eletrofloculação surge como uma técnica promissora, devido à sua eficiência econômica e ambiental com possibilidade de reuso da água. O presente trabalho tem como objetivo estudar o tratamento da água de produção de plataforma de petróleo, através da eletrofloculação, em reator batelada, com eletrodo de alumínio. O estudo enfocou a remoção de poluentes como óleos e graxas (O\&G), cor, turbidez e boro, sendo que os resultados alcançados indicam que, nas condições operacionais estudadas, o processo de eletrofloculação se constitui em uma alternativa tecnicamente viável para a remoção de O\&G, cor e turbidez, obtendo remoção média de $84 \%, 83 \%$ e $83 \%$, respectivamente. Entretanto, não foi observada eficiência na remoção de boro.

Palavras-chave: eletrofloculação, eletrodo de alumínio, água de produção, plataformas off-shore

\begin{abstract}
Treatment of industrial wastewater has grown in the last years and industries have been continuously searching improvements in the treatment's processes based on CONAMA 357/2005 resolution. In this context, the electroflocculation may be a promising alternative due to its economic and environmental benefits, allowing water reuse. This work aims to study the treatment of oil production water by electroflocculation process, with aluminum electrode, in a batch reactor. The study focused on removal of O\&G, color, turbidity and boron. The results indicate that the process of electroflocculation is a technically viable alternative for removal of O\&G, color and turbidity, obtaining average removals of $84 \%, 83 \%$ and $83 \%$, respectively. However, it wasn't efficient to remove boron.
\end{abstract}

Keywords: electroflocculation, aluminium electrodes, water production, off-shore platforms. 


\section{Introduction}

Oil and gas production usually generates extremely large volumes of wastewater. This "produced water" is constituted by the water originally present in the reservoir and the flood water, which is previously injected in the formation water, as well as the condensed water resulting from the gas production. As sea water is injected into the reservoir to maintain pressure on formation for the oil transport, the wastewater is a mixture of sea water and formation water (Vegueria et al., 2001).

Since the formation water usually presents higher salt concentrations and lower $\mathrm{pH}$ than the sea water, the chemical balance is altered with subsequent precipitation of sulphates $\left(\mathrm{BaSO}_{4}\right.$ and $\left.\mathrm{SrSO}_{4}\right)$ and carbonate $\left(\mathrm{CaCO}_{3}\right)$. The volume of water produced in the operation of offshore oil platforms (from 2000 to $40,000 \mathrm{~m}^{3} / \mathrm{d}$ ) is generally greater than the volume of the produced oil. In Brazil, in 1998, an estimated volume of $9.3 \times 10^{6} \mathrm{~m}^{3}$ of water produced was discharged at sea from seven platforms in the Campos Basin (Vegueria et al., 2001).

Water is a by product of oil wells, which is in contact with oil in situ and is subsequently separated from the crude oil.

After separation, a fraction of the water produced is re-injected into the well for additional oil production. The excess should be treated and eliminated.

Often, the decision for reuse depends on the quality of water produced after treatment, as well as on other factors, such as geographic location, extraction procedure, chemical treatment and time of contact with the oil in the formation. The physicochemical composition of the water produced can change its features like salinity, solids, organic and inorganic compounds (including minerals), $\mathrm{pH}$, dissolved oxygen and conductivity (Ma and Wang, 2005).

Due to the large oil production worldwide, large volumes of water production are generated from the phase separation of water / oil in a percentage of $10 \%$ oil and $90 \%$ water, which must be treated for reuse or re -injection, for example.

CONAMA 357/2005 establishes the classification of water bodies and environmental guidelines for its regulatory framework and sets out the conditions and standards for effluent discharge, and other measures. For the case of salt waters the following, among others, are prescribed: oils and greases $=20 \mathrm{mg} / \mathrm{L}$, boron $=$ $5 \mathrm{mg} / \mathrm{L}$ and $\mathrm{pH}$ in the range of 5 to 9 .

Currently, two alternatives for the treatment of these waters are used: (1) chemical processes, including flocculation, filtration and disinfection and (2) physical processes, such as membrane-separation and nanofiltration. The latter, in spite its higher costs, may be used for solids removal and also for reducing both organic and inorganic compounds contents. However, without previous treatment, such as flocculation, many of these compounds, especially those with low molecular weight, are not adequately removed, thus requiring additional treatment of the water produced in order to meet the required characteristics for reuse (Ma and Wang, 2005).

\section{Effluent treatment by Electroflocculation}

Electroflocculation is an application of electrochemical reactors for the treatment of industrial effluents. In the coagulation process, the reactions result from the application of electrical current.

The treatment of effluent through the electrolytic process is comprised by the following stages:

1. The passage of electric current generated by the voltage applied through the entire electrode-electrolyte, causes the decomposition of molecules through oxi-reduction reactions, the decrease of colloidal stability and the formation of a metal cation of the electrode, causing the coagulation and flocculation, and generate gases $\left(\mathrm{H}_{2}\right.$ and $\left.\mathrm{O}_{2}\right)$.

2. The generated gas bubbles are adsorbed at the surface of the flake, thus decreasing the flake density and promotes its flotation.

3. A mechanism for scraping or suction removes the sludge, rich in gas, for a conventional system for drying, while the clarified liquid phase can be directed to a vessel and, if necessary, to a filtering system.

The process of electroflocculation offers an alternative to the use of salts or polyelectrolytes to destabilize emulsions and suspensions. The technology removes metals, colloidal solids, particles and soluble inorganic pollutants in the aquatic environment by the introduction of species of highly charged metal hydroxide. These species neutralize the electrostatic charges on suspended solids to 
facilitate the agglomeration or coagulation and separation of the aqueous phase (Mollah et al., 2001).

\section{Electrical current used in electroflocculation}

As described below, electroflocculation can be applied using either continuous or alternating electrical current:

According Mollah et al. (2001), in the process of electroflocculation by direct electrical current (EDC) a layer of impermeable oxide is formed in both the cathode and the anode, thus causing its deterioration (due to oxidation) and a considerable decrease of the efficiency of the treatment unit. This limitation of the process can be minimized by adding sacrifice plates electrodes in the cell. Because of these limitations, many authors have used alternating current (ACE).

ACE slows the normal mechanism of attack on the electrode, which occurs in EDC and ensure a reasonable lifetime span of the electrode. Moreover, this process can induce dipole-dipole interactions in the system. As a result, the electric field can also disrupt the stability of the balance of dipolar structures in the system. This is not possible in the case of EDC, which minimizes their use (Mollah et al., 2001).

\section{Reactions of the electroflocculation}

According to (Mollah et al. 2001), the mechanism of electroflocculation is highly dependent on the chemical composition of the reactional medium, especially conductivity. Furthermore other process parameters, such as $\mathrm{pH}$, particle size and concentration of constituents also influence electroflocculation.

Another aspect to consider is the adequate selection of electrode materials, being aluminum and iron the most commonly used due to fact that they are cheap, effective and readily available.

\section{Chemical reactions in the presence of aluminum}

The reactions (1) to (4) show what happens when aluminium is used as anode in electroflocculation.

Oxidation of the aluminum anode

$\mathrm{Al}_{(\mathrm{s})} \rightarrow \mathrm{Al}^{3+}{ }_{(\mathrm{aq})}+3 \mathrm{e}^{-}$

$\mathrm{Al}^{3+}{ }_{(\mathrm{aq})}+6 \mathrm{H}_{2} \mathrm{O}_{(\mathrm{l})} \rightarrow \mathrm{Al}\left(\mathrm{H}_{2} \mathrm{O}\right)_{6}{ }^{3+}{ }_{(\mathrm{aq})}$

Formation of coagulant agent:

$\mathrm{Al}\left(\mathrm{H}_{2} \mathrm{O}\right)_{6}{ }^{3+}{ }_{(\mathrm{aq})} \rightarrow \mathrm{Al}(\mathrm{OH})_{3(\mathrm{~s})}+3 \mathrm{H}^{+}$

Secondary reactions:

${ }_{n} \mathrm{Al}(\mathrm{OH})_{3} \rightarrow \mathrm{Al}_{\mathrm{n}}(\mathrm{OH})_{3 \mathrm{n}}$

However, depending on the $\mathrm{pH}$ of the aqueous medium, other ionic species such as $\mathrm{Al}(\mathrm{OH})^{2+}, \quad \mathrm{Al}_{2}(\mathrm{OH})_{2}{ }^{4+}$ e $\mathrm{Al}(\mathrm{OH})_{4}^{-}$may also be present in the system.

Electroflocculation has been used to treat different types of wastewater such as cutting oilwater emulsions (Bensadok et al., 2008), oil suspension for machining and drilling operations (Cansares et al., 2008; Khemis et al., 2005), olive mill wastewater (Tezcan et al., 2006, 2009; Inan et al., 2004), oily bilgewater (Asselin et al., 2008) and mechanical polishing (Drouiche et al., 2007).

The aim of the present work was to study the application of electroflocculation for the treatment of water generated in oil production's platforms, and to determine the best set of values of the operational parameters of process, in terms $\mathrm{pH}$, current density, reaction time, and electrodes consumption (aluminum).

Along these lines, the quality of the treated effluent will be characterized through the monitoring of oil and grease, turbidity, $\mathrm{pH}$, color and boron.

\section{Materials and Methods}

This item describes the analytical procedures for sample collection and measurement of the parameters established in the tests to characterize the effluent.

Provided by PETROBRAS, samples of water from oil production platforms were collected 
in the São Sebastião Terminal, located at the municipality of São Sebastião, São Paulo.

Samples were collected in a tank located between the wastewater and the flotation tanks located at the entry of the treatment plant. Coming from the Campos Basin in Rio de Janeiro, the water produced as well as other types of water are sent by ship to the terminal.

Each sample was collected in a $20 \mathrm{~L}$ polyethylene vessel and stored at room temperature $25^{\circ} \mathrm{C}$.

As illustrated in Figure 1, the experimental procedure consisted of an electroflocculation cell, provided with aluminum electrodes and operated at batch conditions.

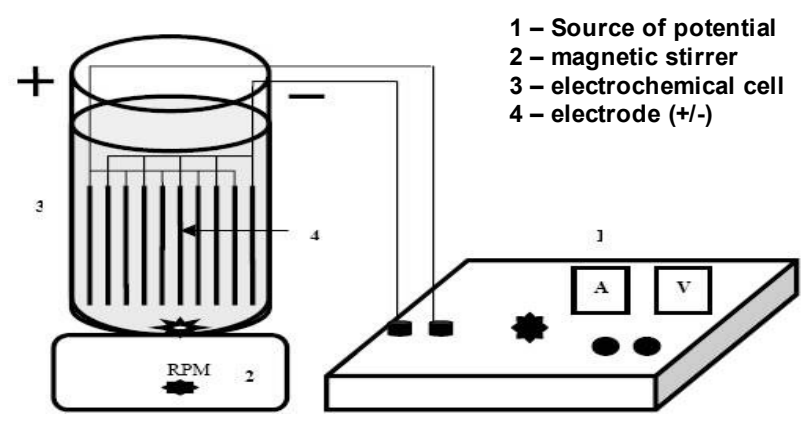

Figure 1 - Diagram of the experimental set-up (Cerqueira, 2006)

The set-up consisted of a $1 \mathrm{~L}$ volume electrolytic cell (Cerqueira, 2006) in which the aluminum electrodes (monopolar, beehive type) were vertically inserted with 7 aluminum plates with $10 \mathrm{~cm}$ height, $5 \mathrm{~cm}$ width and $1,5 \mathrm{~mm}$ thick. The distance between the plates was $5 \mathrm{~mm}$.

The electroflocculation unit consisted of a variable current source, a transformer insulator (with purpose to separate the power grid feeding the primary stage of secondary rectification), an indicator for the current and voltage (for guidance as to parameters applied in the beehive of electrodes).

Samples of both the raw, named gross values, and treated water, named according to the current density applied. Ex: $85 \mathrm{~A} \mathrm{~m}^{-2}=\mathrm{A} 3$, $115 \mathrm{~A} \mathrm{~m}^{-2}=\mathrm{A} 4$ and $145 \mathrm{~A} \mathrm{~m}^{-2}=\mathrm{A} 5$.

The first step was to sample of raw water, being the second step carried out with simulated samples of water production, an emulsion with sea water and $176 \mathrm{mg} / \mathrm{L}$ of oil and grease, prepared at the Laboratory of LARA CENPES.
These samples were used to compare the results obtained with the produced water and in the literature.

After feeding the effluent and introducing of the electrode, the electroflocculation was started and the reactional medium kept under constant agitation.

Samples of both raw and electroflocculated (after filtration) were analyzed for various parameters. The evaluation of efficiency of electroflocculation applied was assessed in terms of oil and grease, as this is the most important pollutant of this type of effluent and to demonstrate the effectiveness in the removal of this pollutant.

\section{Results and Conclusion}

In this stage, tests were conducted, and the samples of produced water and samples of processed water were analyzed. For each sample, the current density of the cell was varied from 85 to $145 \mathrm{~A} \mathrm{~m}^{-2}$ and the time of the cell varied from 2 to $5 \mathrm{~min}$ for each of three samples, and in light of three intensities of applied current, the reversal of polarity of the electrode performed only on 4 and $5 \mathrm{~min}$ in proportion to their total time electroflocculation.

To assess the best results for oils and greases removal, the following parameters as indicated in Table 1, were also measured: color, conductivity, $\mathrm{pH}$, turbidity and boron content.

\section{Characterization of the treated effluent}

Additionally, the analysis of the characterization of the treated effluent was done using the same parameters used for the raw wastewater.

\section{Color}

The results of removing color of raw sewage and electrofloculated in different conditions are shown in Figure 2. 


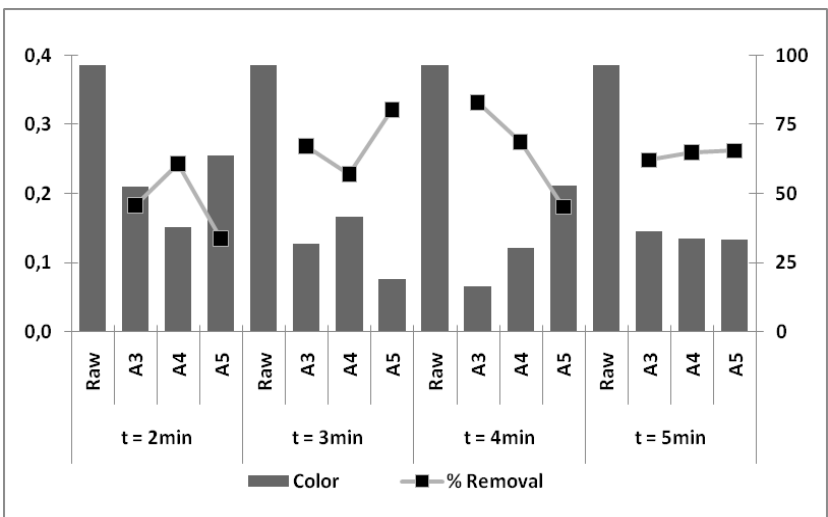

Figure 2 - Removal of color from raw effluent and electroflocculated.

The change of color was detected in samples of irregular way electroflocculated of both tests. You can suggest the likely influence of the electrode oxidation of screws, made of ferrous material, for electroflocculated samples.

\section{Oils and Greases}

The results for O\&G removal for both raw and electroflocculated samples in different conditions are shown in Figure 3. O\&G removal was very high reaching $90.2 \%$ in $\mathrm{A} 4, \mathrm{t}=2$ minutes. To A4, were also obtained the best values for $\mathrm{t}=4$ and $\mathrm{min}=5 \mathrm{~min}$, which may suggest the current density of $115 \mathrm{~A} \mathrm{~m}^{-2}$ ideal for removal of $O \& G$ in detriment to $145 \mathrm{~A} \mathrm{~m}^{-2}$, as the other conditions, according to the best control the electrical voltage, flocculation and flotation.

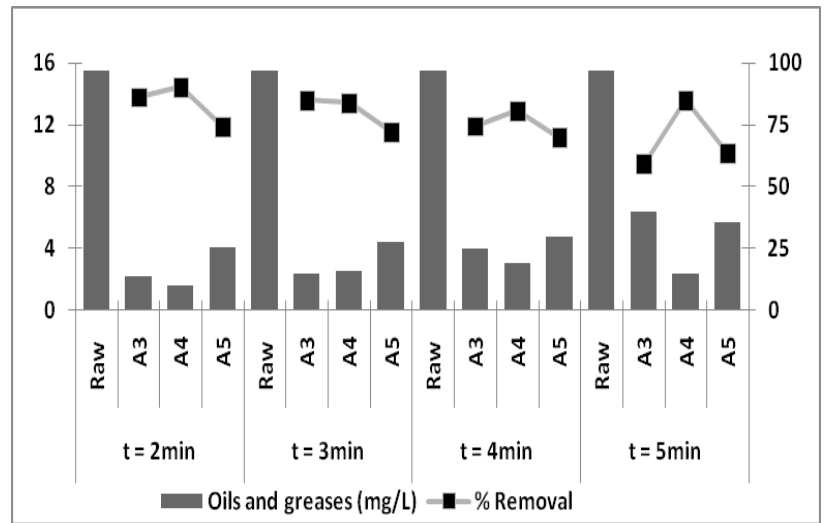

Figure 3 - Removal of oils and greases of raw effluent and electroflocculated.
pH

The results of $\mathrm{pH}$ of the raw sewage and electroflocculated in different conditions are shown in Figure 4.

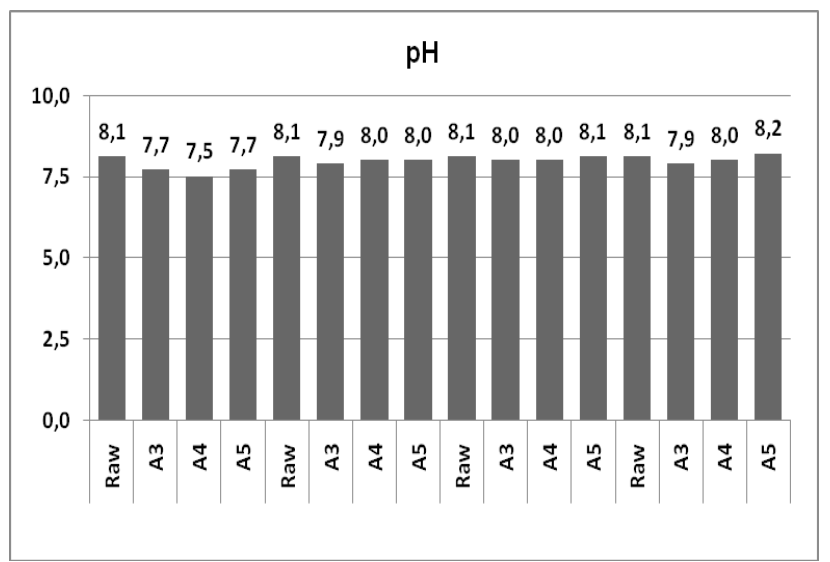

Figure 4 - Behavior of the $\mathrm{pH}$ of raw effluent and electroflocculated.

The $\mathrm{pH}$ is presented in small variations and less alkaline in $t=2 \mathrm{~min}$. This test showed the highest value of $\mathrm{pH}$ for their samples, on the other.

\section{Turbidity}

The results for removal of turbidity of raw sewage and electroflocculated in different conditions are shown in Figure 5. Good result was obtained for $\mathrm{t}=3 \mathrm{~min}$, explained the proper control of $\mathrm{pH}$ and its linearity and the homogeneity of the content of oils and greases in their current density. The same occurred for $t=4$ min, except for A5, where there was interference of suspended solids from, probably, the wear of the screws of the iron electrode.

Bensadok et al. (2008) found optimum $\mathrm{pH}$ 6 to 7 for removal of $99 \%$ of turbidity, using aluminum electrodes. 


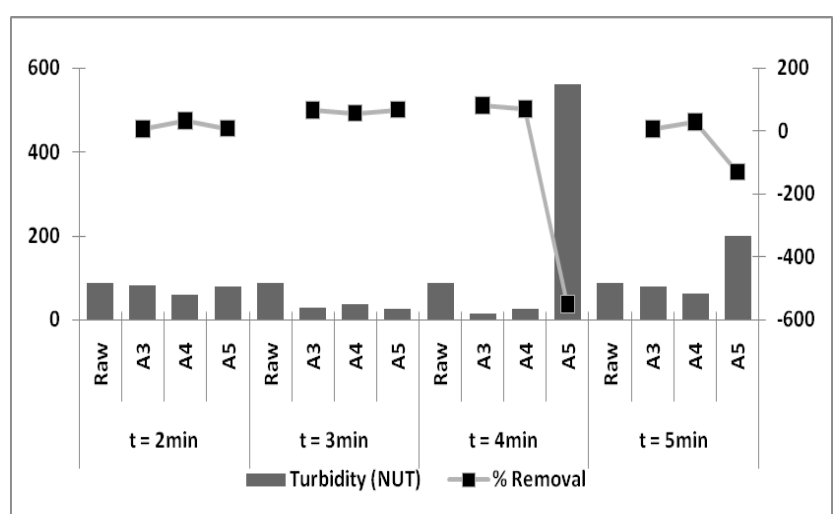

Figure 5 - Removal of turbidity of raw effluent and electroflocculated

\section{Boron}

Analysis of boron in the effluent and raw electroflocculated in different conditions are presented in Figure 6.

The percentage of removal of boron reached $14.3 \%$ for the $\mathrm{A} 5$, at $\mathrm{t}=4 \mathrm{~min}$, but continued down to the other and $A 3, t=2 \mathrm{~min}$. This may be explained by the high conductivity of the effluent and the $\mathrm{pH}$ around the neutral range, which decreases the removal of the substance, despite the high amount of boron in the sample gross.

The value of $17.1 \mathrm{mg} / \mathrm{L}$ also restricts the disposal of effluent, under CONAMA 357/05, which allows up to $5.0 \mathrm{mg} / \mathrm{L}$ in salt water for disposal.

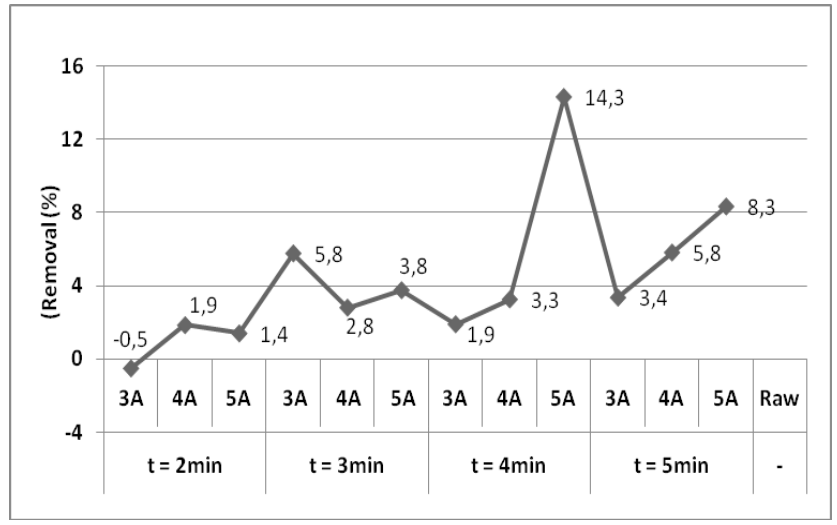

Figure 6 - Removal of boron from raw effluent and electroflocculated.

For boron removal, Yilmaz et al. (2005) applied electroflocculation using 100, 250, 500 and $1000 \mathrm{mg} / \mathrm{L}$ samples and obtained better results for $100 \mathrm{mg} / \mathrm{L}$, at $\mathrm{pH}=8$ with low conductivity effluent. In this step, the $\mathrm{pH}$ was not measured. However, for comparative purposes, the range of values obtained in step 1 (6.4 - 7.5) can serve as a reference for this step, once the effluent has the same source.

In this step, we analyzed the gross sample of an emulsion prepared with sea water and oil and three samples treated by their electroflocculation, the density of electric current of the cell varied from 85 to $145 \mathrm{~A} \mathrm{~m}^{-2}$, for each sample. The time of testing ranged from 2 to 5 min for each of the three samples, and in light of three densities of applied current, the reversal of polarity of the electrode held in only $4 \mathrm{~min}$ and 5 min, proportional to their time.

All parameters were analyzed to compare the results obtained with the emulsion prepared from water and original production. Furthermore, it was particularly examined the weight of the electrode to quantify the wear of it.

\section{Characterization of raw sewage}

Compared to previous results, this sample presented higher values of oils and greases, color and $\mathrm{pH}$ and lower values of conductivity and boron (Table 2).

\section{Characterization of effluent electroflocculated}

The characterization of the treated effluent was performed using the same parameters described for the raw sewage.

\section{Color}

The results of removing the color of raw sewage and electroflocculated in different conditions are shown in Figure 7.

The color of the crude sample was reddish, depending on the oil mixed to form the emulsion. The removal of color was considered optimal, constant and proportional to the current density applied, reaching $93 \%$ in A4 and $5=\min$. There were no factors that could interfere with the removal of color. 


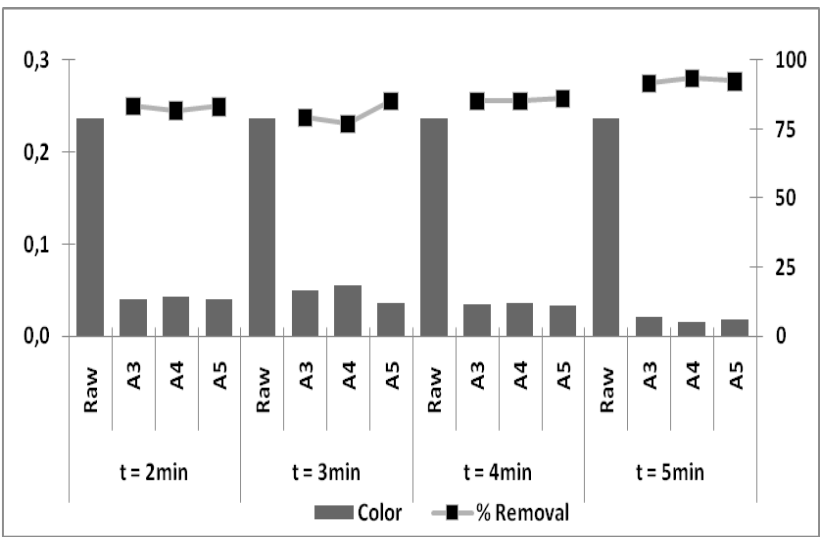

Figure 7 - Removal of color from raw effluent and electroflocculated.

\section{Oils and greases}

The results of removing oils and grease from the effluent and raw electroflocculated in different conditions are shown in Figure 8.

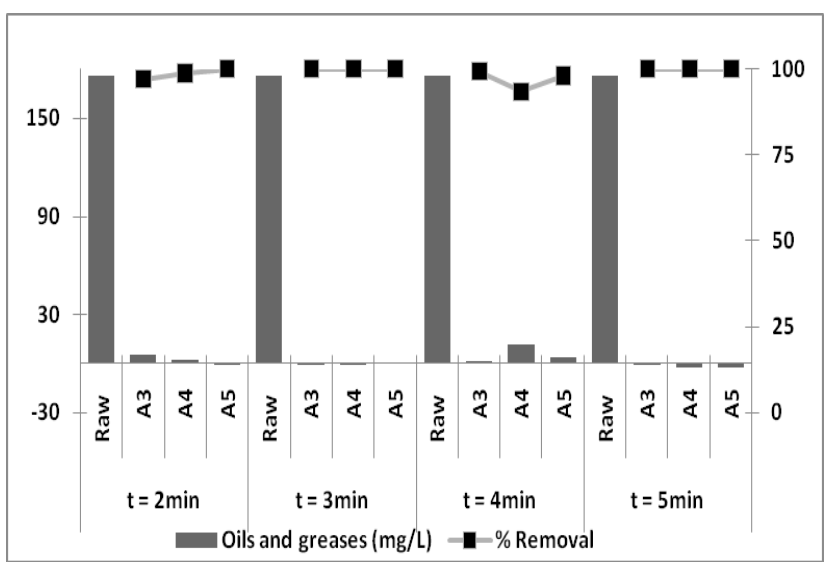

Figure 8 - Removal of oils and greases of raw effluent and electroflocculated.

The removal of oils and greases reached $100 \%$ for $t=3 \mathrm{~min}=5 \mathrm{~min}$ and at all levels of current and also to $\mathrm{A} 5$, at $\mathrm{t}=2 \mathrm{~min}$. This may have been given in terms of linearity of the $\mathrm{pH}$, and proximity of the 7th Figure 9 shows the process of electroflocculation at $t=5 \mathrm{~min}$ and the current density equal to $85 \mathrm{~A} \mathrm{~m}^{-2}$.

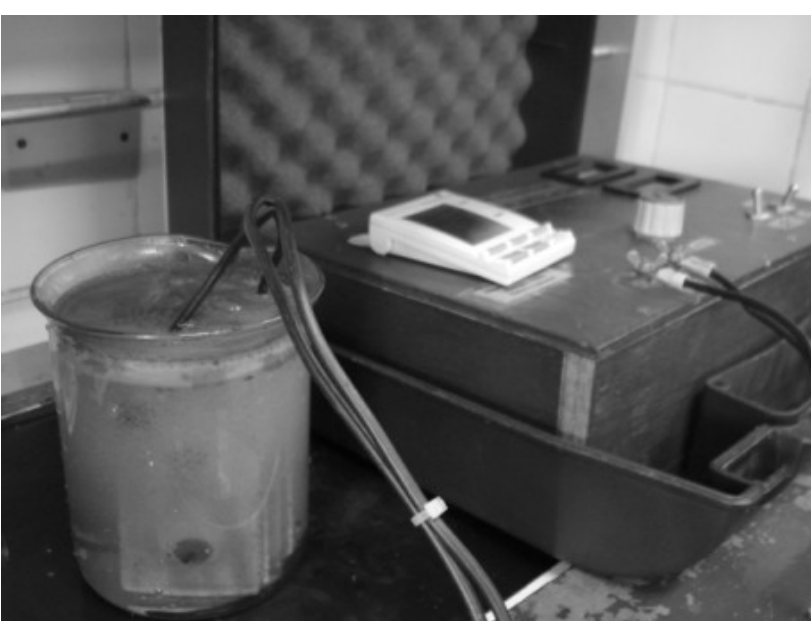

Figure 9 - Electroflocculation to $\mathrm{A} 3$, at $\mathrm{t}=5 \mathrm{~min}$.

$\mathrm{pH}$

The results of $\mathrm{pH}$ of the raw sewage and electroflocculated in different conditions are shown in Figure 10.

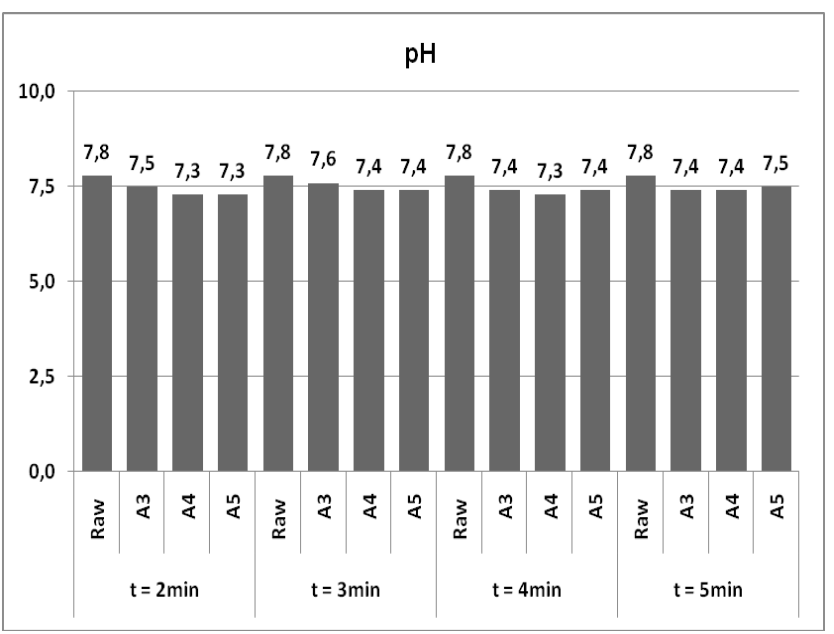

Figure 10 - Behavior of the $\mathrm{pH}$ of raw effluent and electroflocculated.

The $\mathrm{pH}$ of the crude sample was reduced during the tests, getting close to neutrality to remain practically linear, which may have influenced the removal of oils and greases and turbidity reached. 


\section{Turbidity}

The results of removal of turbidity of raw sewage and electroflocculated in different conditions are shown in Figure 11.

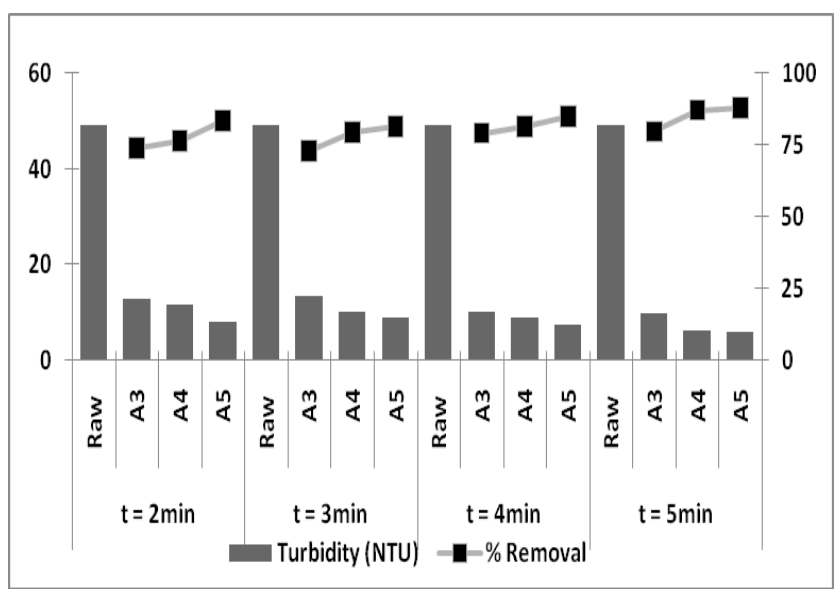

Figure 11 - Removal of turbidity of raw effluent and electroflocculated.

Turbidity has behaved in a satisfactory way, showing the best results of the study. Removal reached $88 \%$ in the $\mathrm{A} 5=5 \mathrm{~min}$, according to the good control of the current density and near neutral $\mathrm{pH}$.

\section{Weight of the electrode}

The electrode was heavy in the last stage, before and after the electroflocculations in order to obtain parameters that could show the wear of it.

The value of $404.80 \mathrm{~g}$ was initiated at the end of $402.60 \mathrm{~g}$. The difference of $2.20 \mathrm{~g}$ is explained by the oxidation of the aluminum electrode in $\mathrm{Al}^{3+}$ and the subsequent formation of hydroxide, $\mathrm{Al}(\mathrm{OH})_{3}$.

The use of electroflocculation in the treatment of industrial effluents is a very efficient process for removal of various pollutants, leading to reduction of important parameters such as color, turbidity and the content of oils and greases.

In this work, using the electrode with electroflocculation aluminum applied to the treatment of water production, characteristic of oily wastewater.
For samples of water production, the best combinations of efficiency of removal of pollutants, using an aluminum electrode was at $t$ $=4 \mathrm{~min}$, with an current density of $85 \mathrm{~A} \mathrm{~m}^{-2}$ and $\mathrm{pH}$ equal to to 8.1 in alkaline range. Color: $83 \%$, oils and grease: $84 \%$, Turbidity: $83 \%$.

For the case of produced water (simulated) and operating under the following conditions, namely, $\mathrm{t}=5 \mathrm{~min}$, current density of $145 \mathrm{~A} \mathrm{~m}^{-2}$, and initial $\mathrm{pH} \mathrm{7.8,} \mathrm{the} \mathrm{results} \mathrm{obtained}$ were: color: $92 \%$, oils and greases: $100 \%$, turbidity: $88 \%$. In the case of boron, however, extremely low removal efficiencies were obtained $(14 \%)$.

The results showed the efficiency of the electroflocculation in the treatment of water for production using an aluminum electrode. This process is very interesting from an environmentastandpoint when compared to the conventional process for the removal of toxic substances, and economics, for automation and may show lower maintenance costs. It is suggested to try different $\mathrm{pH}$ values and operating temperature during electroflocculation with ACE and EDC to assess the effect of these parameters in the process.

\section{References}

1) ASSELIN, M.; DROGUI, P.; KAUR BRAR, S.; BENMOUSSA, $H_{\text {.; }}$ BLAIS, J. Organics removal in oily bilgewater by electrocoagulation process. Journal Hazardous Materials, 2008, 151, 446-455.

2) BENSADOK, K.; BENAMMAR, S.; LAPICQUE, F.; NEZZAL, G., Electrocoagulation of cutting oil emulsions using aluminium plate electrodes. Journal Hazardous Materials, 1, 152, pp. 423-430, 2008.

3) CANSAREZ, P.; MARTINEZ, F.; JIMENEZ, C.; SAEZ, C.; RODRIGO, M., $2008 . \quad$ Coagulation and electrocoagulation of oil-in-water emulsion. Journal Hazardous materials 151, 44-51.

4) CERQUEIRA, A. A., Aplicação da Técnica de Eletrofloculação no Tratamento de Efluentes Têxteis. $M$. Sc., Dissertation, Universidade do Estado do Rio de Janeiro, Brazil, 2006. 
5) CONSELHO NACIONAL DO MEIO AMBIENTE (CONAMA) (Brasil). Resolução $n^{\circ}$ 357, de 17 de março de 2005. Dispõe sobre a classificação dos corpos de água e diretrizes ambientais para o seu enquadramento, bem como estabelece as condições e padrões de lançamento de efluentes, e dá outras providências.

6) DROUICHE, N. GHAFFOUR, N. LOUNICl, $\quad H$.; MAMERI, M. Electrocoagulation of chemical mechanical polishing wastewater. Desalination, 2007, 214, 31-37.

7) INAN, H.; DIMOGLO, A.; SIM, H.; KARPUZCU, $M$. Olive oil Mill wastewater treatment by means of electrocoagulation. Separation Purify Technology, 2004, 36, 23-31.

8) KHEMIS, M.; TANGUY, G.; LECLERC, J. P.; VALENTIN, G.; LAPICQUE, F., Electrocoagulation for the treatment of oil suspensions. Trans IChem ${ }^{\mathrm{E}}, 2005,83$ (B1), 50-57.

9) MA, H.; WANG, B., Electrochemical pilot-scale plant for oil field produced wastewater by $\mathrm{M} / \mathrm{C} / \mathrm{Fe}$ electrodes for injection. Journal Hazardous Materials, 2-3, 132, pp. 237-243, 2005.

10) MOLLAH, M. Y. A.; SCHENNACH, R.;
PARGA, J. R.; COCKE, D. L., Electrocoagulation (EC): science and applications. Journal Hazardous Materials, 1, 84, pp. 29-41, 2001

11) TEZCAN, U.; KOPARAL, A. S.; OGUTVEREN, U. B., Electrocoagulation of vegetables oil refinery wastewater using aluminum electrodes. Journal of Envir Management, 2009, 90, 428-433.

12) TEZCAN, U; UGUR, S.; KOPARAL, A. S.; OGUTVEREN, U. B., Electrocoagulation of olive mill wastewaters. Separation and Purification Technology, 2006, 52, 136-141.

13) VEGUERIA, S. F. J.; GODOY, J. M.; MIEKELEY, N. Environmental impact studies of barium and radium discharges by produced waters from the "Bacia de Campos" oil-field offshore platforms. Journal Environmental Radioactive. 1, 62, pp. 2938, 2001

14) YILMAZ, A. E.; BONCUKCUOĞLU, R.; KOCAKERIM, R. M.; KESKINLER, B., The investigation of parameters affecting boron removal by electrocoagulation method. Journal Hazardous Materials, 1-3, 125, pp. 160165, 2005.

Table 1: Characterization of raw effluent

\begin{tabular}{l|c}
\hline \multicolumn{1}{c|}{ Parameters } & Values \\
\hline Boron (mg/L) & 19,9 \\
Conductivity (mS/cm) & 86,3 \\
Color (Abs.) & 0,385 \\
Oil and greases (mg/L) & 15,3 \\
pH & 8,1 \\
Turbidity (NTU) & 86,3 \\
\hline
\end{tabular}

Table 2 - Characteristics of raw effluent (simulated).

\begin{tabular}{l|c}
\hline \multicolumn{1}{c|}{ Parameters } & Values \\
\hline Boron (mg/L) & 2,78 \\
Conductivity (mS/cm) & 85,0 \\
Color (Abs.) & 0,237 \\
Oil and greases (mg/L) & 176,4 \\
pH & 7,8 \\
Turbidity (NTU) & 49,3 \\
\hline
\end{tabular}

